\title{
Hydrophobic Surfactant-Associated Protein in Whole Lung Surfactant and Its Importance for Biophysical Activity in Lung Surfactant Extracts Used for Replacement Therapy
}

\author{
JEFFREY A. WHITSETT, BRYAN L. OHNING, GARY ROSS, JOSEPH MEUTH, \\ TIMOTHY WEAVER, BRUCE A. HOLM, DONALD L. SHAPIRO, AND ROBERT H. NOTTER \\ Departments of Pediatrics, University of Cincinnati, Cincinnati, Ohio [J.A.W., B.L.O., G.R., T.W.J and \\ University of Rochester, Rochester, New York [B.A.H., D.L.S., R.H.N.]
}

\begin{abstract}
Hydrophobic protein of 6,000 and 14,000 daltons was isolated from mammalian pulmonary surfactant obtained from canine, human, and bovine alveolar lavage material. Low molecular weight, hydrophobic, surfactant-associated protein (SAP), herein referred to as SAP 6-14, was distinguished from SAP-35, the major glycoprotein in mammalian surfactants (the 35,000 dalton glycoprotein A or apolipoprotein A) by amino acid composition, peptide mapping, and by resistance of SAP 6-14 to digestion by endoglycosidase $\mathrm{F}$, collagenase, trypsin, and other proteases. The amino acid composition of SAP 6-14 was found to be highly enriched in leucine and other hydrophobic amino acids. The characteristics of protein isolated from bovine replacement surfactant extracts utilized for the treatment of hyaline membrane disease in humans were also studied. SAP 6-14 isolated from calf lung surfactant replacement extracts (CLSE) and surfactant-TA were found to be identical to SAP 6-14 isolated from ether/ethanol extracts of various mammalian surfactants. By contrast, SAP-35, the major surfactant-associated glycoprotein of molecular weight $=35,000$, and other higher molecular weight proteins were not detected in significant quantities in the CLSE or surfactant-TA replacement surfactants, either by highly sensitive silver stain analysis or by immunoblot using monospecific antisera generated against bovine SAP-35. Biophysical studies of the CLSE replacement surfactant containing only SAP 6-14 and native phospholipids demonstrated full surface activity compared to natural lung surfactant. Dynamic surface tension lowering and adsorption properties of CLSE were essentially identical to those of freshly isolated bovine whole surfactant. Thus, hydrophobic SAP 6-14 is the only protein detected in bovine lung extract surfactants with full biophysical activity. The major surfactant associated protein, SAP-35, was not a significant component of either the CLSE or surfactant-TA replacement preparations. (Pediatr Res 20: 460-467, 1986)
\end{abstract}

\section{Abbreviations}

Mr, molecular weight

SAP 6-14, surfactant-associated protein of $\mathrm{Mr}=\mathbf{6 , 0 0 0}$ and 14,000 daltons

Received November 12, 1985; accepted January 9, 1986

Address for correspondence Jeffrey A. Whitsett, M.D., University of Cincinnati, College of Medicine, Department of Pediatrics, Neonatology Division, 231 Bethesda Avenue, Cincinnati, OH 45267-054i.

This work was supported in part by Research Career Development Awards HL00945 (RHN) and HL-10124 (JAW) from the National Institutes of Health, by NIH Grants HL-28623, HD-11725, and HL-25170, and by a grant from the Children's Hospital Research Foundation, Cincinnati, $\mathrm{OH}$.
SAP 35, surfactant-associated protein of $\mathrm{Mr}=35,000$ daltons

CLSE, calf lung surfactant extract

LS, lung surfactant

SAP, surfactant-associated protein

Mammalian pulmonary surfactant is a complex material containing primarily phospholipids and associated proteins or apolipoproteins. Evidence from a number of laboratories supports the concept that in addition to lung surfactant phospholipids, some of these protein components are required for the full biological activity of surfactant in reducing surface tension in the alveoli (1-8). Several exogenous surfactant preparations that are based on organic solvent extraction of mammalian lung lavage and contain only small amounts of lung protein (1-2\%) have been successfully utilized in the treatment of hyaline membrane disease. Such lung surfactant extracts were used in initial clinical studies by Smyth et al. (9) and Fujiwara et al. (10). Efficacy for a specific CLSE has now been demonstrated in three recent controlled, double-blind clinical trials by Kwong et al. (11), Shapiro et al. (12), and Enhorning et al. (13) for the prevention of hyaline membrane disease in infants. One of the aims of the present work is to define in more detail the protein composition of the biophysically and physiologically active surfactant replacement extract preparations CLSE $(9,11-13)$ and surfactant-TA (14).

The major surfactant-associated protein of $\mathrm{Mr}=30-40,000$ daltons, first identified in lung surfactant by King et al. (16), are glycoproteins rich in glycine and containing collagen-like regions rich in hydroxyproline $(17,18)$. This protein, herein called SAP35 , is synthesized from $\mathrm{Mr}=28-30,000$ dalton translation products which undergo glycosylation, hydroxylation of proline residues, and sulfhydryl-dependent cross-linking to form larger oligomers which are detected in the airway (19-25). SAP-35 and smaller surfactant-associated proteins have also been identified from a variety of mammalian surfactants (24-33).

The nature and relationships among the various SAPs and the larger protein, SAP-35 or its fragments, have not been entirely established. It has been suggested that smaller molecular weight proteins arise as proteolytic fragments of the larger molecule (32). It is, however, possible that one (or more) of the smaller molecular weight proteins in lung surfactant is a distinct entity with independent function and importance. It is thus unclear at present whether SAP-35, one or more of the smaller proteins, or all proteins together are active components imparting biophysical activity to mammalian surfactant. In the present work we have 
purified and partially characterized hydrophobic protein of $\mathrm{Mr}$ $=6,000$ and 14,000 daltons from the surfactant of several mammalian species, herein called SAP 6-14. The characteristics of this protein are compared and contrasted with those of SAP-35 and its fragments. These results are also correlated with data on the hydrophobic protein found in the surfactant replacement extract preparations CLSE and surfactant-TA to support a role of SAP 6-14 in surfactant function.

\section{MATERIALS AND METHODS}

SAP from mammalian lung lavage surfactant. SAP were isolated from lung lavage material obtained from adult dogs and cows after sacrifice. In addition, proteins were isolated from human surfactant obtained from human cadavers following autopsy, from human amniotic fluid at term and from selected bronchial washes from the lungs of patients with alveolar proteinosis. Protocols involving human material were approved by the Committee on Human Research, University of Cincinnati College of Medicine. In animal studies, the trachea was cannulated and the lung lavaged three times with several lung volumes of iced $0.9 \% \mathrm{NaCl}, 50 \mathrm{mM} \mathrm{Na}_{2} \mathrm{HPO}_{4}$, and $5 \mathrm{mM}$ EDTA, $\mathrm{pH}$ 7.2. Cells and debris were removed by centrifugation at $800 \times g$ for $10 \mathrm{~min}$ (twice) and a particulate fraction was then collected by centrifugation at $40,000 \times g$ for $30 \mathrm{~min}$ at $4^{\circ} \mathrm{C}$. The pelleted material was diluted in the above buffer containing $1 \mathrm{mM}$ phenylmethylsulfonylfluoride and sonicated for $10 \mathrm{~s}$ with a Branson sonifier. Surfactant was then pelleted by centrifugation at $40,000 \times g$ for $30 \mathrm{~min}$ at $4^{\circ} \mathrm{C}$.

The surfactant pellet was further processed by extraction in ether/ethanol (3:1) at $-30^{\circ} \mathrm{C}$ for $16 \mathrm{~h}$ (16). Particulate material was removed from the extraction by centrifugation and utilized for the purification of SAP-35 as previously described $(17,23)$. Ether/ethanol fractions containing SAP 6-14 were evaporated to near dryness and redissolved in chloroform. Purification of SAP 6-14 then proceeded essentially as described by Phizackerley et al. (30). The dried residue was dissolved in chloroform and applied to a BioSil HA column $(2.5 \times 40 \mathrm{~cm}$, Bio-Rad, Richmond, CA) equilibrated in chloroform. Lipid-protein fractions were recovered by stepwise elution with chloroform-methanol mixtures $(200 \mathrm{ml}$ each) with stepwise increase in concentration of methanol ( $10 \%$ intervals) in chloroform. Aliquots from each column fraction were assayed for protein by SDS-PAGE (see below). The purified protein was also quantitated by a fluorescamine assay using bovine serum albumin as standard in the presence of $1 \%$ SDS (34). However, lipid eluting earlier than SAP 6-14 on the silicic acid column also reacted with fluorescamine and thus this assay could not be used to quantitate the amount of protein applied or recovered.

SAP from surfactant replacement preparations. CLSE was prepared by chloroform-methanol extraction (35) from saline lavage of calf lungs as described in detail previously by Notter and coworkers $(2,3,11,12,36,37)$. Whole calf LS was also obtained from the same lavage sample by centrifugation after cell removal (2), and was used for comparative analysis of biophysical properties as described later. The phospholipid composition of whole LS and CLSE was defined by thin layer chromatographic analysis with the solvent system of Touchstone et al. (38). The phospholipid class distribution was $81 \%$ phosphatidylcholine, $6.7 \%$ phosphatidylglycerol, $6 \%$ phosphatidylinositol (+phosphatidylserine), $4.3 \%$ phosphatidylethanolamine, and $2 \%$ sphingomyelin. The CLSE contained $94 \%$ phospholipid by weight while natural LS from the same lavage was $86 \%$ phospholipid [based on an overall phospholipid molecular weight average of 750 daltons, and using the microphosphorous assay of Ames (39)]. The total protein content of the CLSE preparation was $<1.5 \%$, compared to $11 \%$ for natural LS, using a modification of the method of Lowry et al. (40) in which the assay was performed in $1.0 \%$ SDS to analyze for protein in the presence of lipid. The remainder of both LS and CLSE was predominantly the neutral lipid cholesterol.

The surfactant replacement extract preparation, surfactant-
TA, was also analyzed for SAP. This preparation was provided through the cooperation of Abbott Laboratories, N. Chicago, IL. Surfactant-TA is a chloroform-methanol extract of minced lungs from cows, supplemented with dipalmitoyl phosphatidylcholine and other phospholipids and neutral lipids including free fatty acids (14). Fujiwara (14) has presented the representative chemical composition of surfactant-TA lipid, which comprises about $98 \%$ of the mixture. The remainder of the preparation, approximately $2 \%$, is protein.

Further detailed analysis of the surfactant-associated protein remaining in CSLE and surfactant-TA after chloroform-methanol extraction was carried out essentially as described above. CLSE or surfactant-TA was placed in chloroform:methanol (2:1) prior to gel analysis. A small amount of flocculent material precipitated from the chloroform:methanol solution was removed by centrifugation at $10,000 \times g$ for 20 min before rotoevaporation, addition of chloroform and application to silicic acid columns. In some cases, protein was further delipidated prior to analysis using Sep-packs from Waters, Inc., Milford, MA. CLSE and surfactant-TA protein was applied to the Seppack in chloroform and eluted from the column with increasing concentrations of methanol.

Gel analysis of SAP. Proteins were analyzed after separation using SDS-polyacrylamide gels (Integrated Separations Systems Inc., from Fisher Scientific, Cincinnati, OH) made either 3-27 or $10-20 \%$ polyacrylamide. Samples were lyophilized and resuspended in sample buffer as described by Laemmli (41), in the presence of $\beta$-mercaptoethanol. Gels were stained using slight modification of the procedures of Sammons et al. (42) in which $5 \%$ acetic acid was used to control background staining following a 5-10 min $\mathrm{Na}_{2} \mathrm{CO}_{3}$ color development step. Molecular weight markers included trypsin inhibitor $(6,300)$, lysozyme $(14,000)$, $\beta$-lactalbumin $(18,400), \alpha$-chymotrypsin $(25,700)$, and ovalbumin $(43,000)$ purchased from BRL Incorporated, Bethesda, MD.

Immunoblot analysis of bovine SAP. Monospecific antisera was prepared against bovine SAP-35 by repeated injection of approximately $500 \mu \mathrm{g}$ of the protein in Freund's complete adjuvant into rabbits. Antigen was homogeneous as assessed by silver staining of one- and two-dimensional SDS-PAGE analysis. The resultant antisera were not reactive against bovine serum albumin or bovine serum. For immunoblot analysis, whole bovine surfactant was separated by SDS gel electrophoresis and subjected to immunoblot as previously described (23). Proteins were transferred electrophoretically to nitrocellulose, treated with anti-SAP35 antibody followed by horseradish peroxidase-conjugated goat anti-rabbit IgG, and developed as described by Towbin et al. (43) except that $0.05 \%$ 4-chloro-napthol was used as the substrate.

Analysis of protein utilizing protease and endoglycosidase treatment. Purified canine SAP-35 and purified canine SAP 614 were resuspended in $1 \%$ SDS. Aliquots were then diluted in indicated buffers with the following concentrations of digestive enzymes: endoglycosidase $\mathrm{F}$ ( $50 \mathrm{mM}$ sodium phosphate, $\mathrm{pH} 6.1$ $0.1 \% \mathrm{NP}-40,10 \mathrm{mM}$ disodium EDTA, and 0.1 to $4 \mathrm{U}$ of endoglycosidase $\mathrm{F}$ per $\mathrm{ml}$ ); collagenase $(50 \mathrm{mM}$ Tris- $\mathrm{HCl}, \mathrm{pH}$ $7.3,150 \mathrm{mM} \mathrm{NaCl}, 0.1 \% \mathrm{NP}-40,0.5 \mathrm{mM} \mathrm{MgSO}_{4}, 0.5 \mathrm{mM}$ $\mathrm{CaCl}_{2}$, and 3-100 U of bacterial collagenase per ml); and neuraminidase $(50 \mathrm{mM}$ sodium acetate, $\mathrm{pH} 5.5,150 \mathrm{mM} \mathrm{NaCl}, 4 \mathrm{mM}$ $\mathrm{CaCl}_{2}$ and $0.1-0.3 \mathrm{U}$ of neuraminidase per $\mathrm{ml}$ ). Digestions were carried out at $37^{\circ} \mathrm{C}$ for 16 to $20 \mathrm{~h}$. In the case of SAP 6-14, proteolytic digestion was repeated by the subsequent additions of identical amounts of degrading enzymes. Tryptic maps were prepared after iodinating the proteins by the chloramine $T$ method, as previously described (23). Iodinated proteins were cut from the gel and resuspended in $50 \mathrm{mM}$ sodium acetate, $\mathrm{pH}$ 8 , and incubated with chymotrypsin $(50 \mu \mathrm{g} / \mathrm{ml})$ and trypsin $(50$ $\mu \mathrm{g} / \mathrm{ml}$ ) for $16 \mathrm{~h}$ at $24^{\circ} \mathrm{C}$. Iodopeptides were then isolated by electrophoresis and thin-layer chromatography as described by Gibson (44) and subjected to autoradiography in parallel with peptides from SAP-35. In separate experiments trypsin digests of the canine SAP-35 were performed in the presence and absence of both $1 \%$ NP-40 or $1 \%$ SDS. 
Amino acid composition of SAP. SAP-35 and hydrophobic protein SAP 6-14 from canine and bovine surfactants were purified, reduced, and alkylated and hydrolyzed in $30 \mu \mathrm{l}$ of 5.0 $\mathrm{M} \mathrm{HCl}$, containing $0.3 \%$ phenol, $0.1 \% \beta$-mercaptoethanol at $110^{\circ}$ under vacuum (17). Free amino acids were determined using a Beckman 6300 amino acid analyzer.

Biophysical analyses of CLSE surfactant activity. Biophysical characterizations of surfactant activity were carried out by two techniques: 1) adsorption measurements in the absence of a diffusion resistance and 2) dynamic surface tension lowering utilizing an oscillating bubble apparatus. Details of adsorption experiment methodology have been given previously by Notter and coworkers $(2,3,36,37)$. In brief, aliquots of a surfactant dispersion were added at time zero to a stirred surfactant-free subphase, and subsequent surface tension lowering followed as a function of time using a sandblasted platinum Wilhelmy slide connected to a force transducer. Adsorption measurements were made at $35 \pm 2^{\circ} \mathrm{C}$. In addition to isolated adsorption facility, an oscillating bubble apparatus, equivalent in design to that of Enhorning (45), was used to measure a combination of dynamic surface tension lowering, respreading, and adsorption properties as described in detail by Notter and coworkers $(3,36,37)$. Bubble measurements were made at $37^{\circ} \mathrm{C}$ and $100 \%$ humidity, with a cycling rate of 20 cycles/min and an area compression of $50 \%$.

\section{RESULTS}

Characteristics of SAP-35 and SAP 6-14. Extraction of whole lung surfactant from all species studied (human, dog, cows, rats) with ether/ethanol results in separation of the two major protein components of surfactant. Using the ether/ethanol extraction technique, the insoluble material contains virtually all of the SAP-35, $\mathrm{Mr}=32,000-36,000$ daltons (after sulfhydryl reduction) which was readily detected by Coomassie (Fig. 1) and silver staining analysis or by immunoblot with monospecific anti-

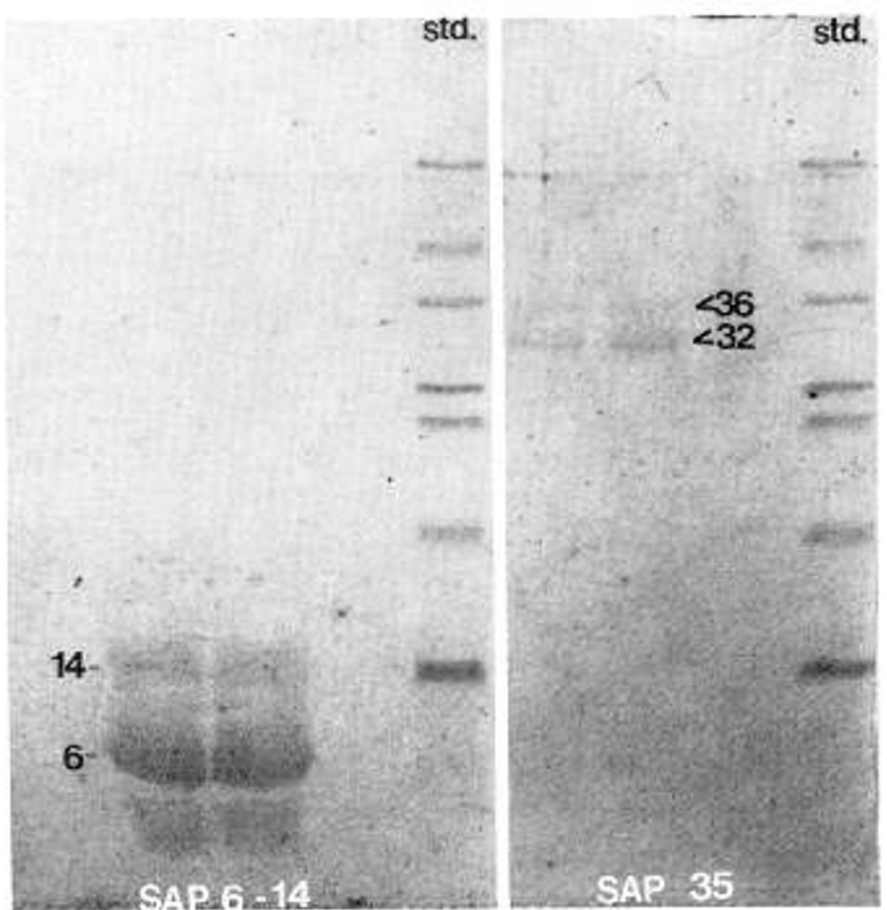

Fig. 1. Coomassie-stained analysis of the major surfactant-associated proteins. Figure 1 represents two lanes of approximately $5 \mu \mathrm{g}$ of purified SAP 6-14 migrating in relation to the 14,000 dalton marker protein on a $3-27 \%$ gradient SDS-PAGE gel (left lanes). The lanes to the right represent two lanes of $5 \mu \mathrm{g}$ each of purified SAP-35 (the glycosylated forms migrate $\mathrm{Mr}=32,000$ and 36,000). Standard marker proteins are seen in the right lane. canine or anti-bovine SAP-35 antisera generated against either bovine or canine SAP-35, respectively. This precipitate does not contain SAP 6-14. Conversely, ether/ethanol soluble fractions did not contain detectable SAP-35 by either method and were utilized for purification of SAP 6-14. Purified SAP 6-14 from the canine preparation is seen on Figure 1.

The abundance of lipid in the starting material for SAP analyses made precise demonstration of any small molecular weight protein components impossible. Silver stained material and lipid migrate with the solvent front (Fig. $2 A$ ). However, purification and delipidation of the ether/ethanol extractable protein and subsequent analysis by SDS-PAGE resulted in detection of silverstained material (Fig. 2) or Coomassie stained material (Fig. 1) which migrated with $\mathrm{Mr}=6,000$ and 14,000 daltons. Protein purification for these analyses began by elution from silicic acid columns at approximate concentrations of $2: 3$ chloroform:methanol as the eluant solvent (Fig. $2 C$ ). Silver stained material at $\mathrm{Mr}=6,000$ and 14,000 correlated with a protein peak eluted from the column as assessed by the fluorescamine assay (not shown), although a major lipid fraction was also reactive with fluorescamine but lacked SAP 6-14 by gel analysis. Delipidated, ether/ethanol soluble proteins were purified from bovine, canine, and human natural lung surfactant as represented by Figure 3 . In all species, protein migrating with molecular weight 6,000 and 14,000 daltons was the only protein detected in the ether/ethanol soluble fraction. As shown in Figures 2 and 3 , this protein of $\mathrm{Mr}=6,000$ and 14,000 daltons could be resolved into two distinct bands utilizing SDS-PAGE gradient gels and various staining methods. When larger amounts of protein were loaded, bands were also detected at $\mathrm{Mr}=20,000$ and $\mathrm{Mr}=26,000$, the large forms likely representing oligomers of SAP- 6,000 .

To determine whether the 6-14,000 dalton protein was structurally similar to the major SAP, SAP-35, both proteins were subjected to digestion with a number of proteases and with endoglycosidase $F$. As in previous studies $(19,21,23)$, canine SAP-35 was degraded by endoglycosidase F, which cleaves asparagine-linked oligosaccharides, with a resultant $\mathrm{Mr}=28-$ 30,000 dalton form of canine protein. Since the 35,000 dalton SAP-35 is also known to be sensitive to bacterial collagenase and trypsin $(17,21,23)$, similar digestions with thermolysin and papain was carried out with SAP 6-14. In all cases, SAP 6-14 hydrophobic proteins were entirely resistant to protease treatment in marked contrast to the susceptibility of SAP-35. Boiling the sample, the addition of $1 \% \mathrm{NP}-40,1 \%$ SDS or $6 \mathrm{M}$ urea prior to digestion, as well as repeated digestions, all failed to cleave SAP 6-14 under conditions in which SAP-35 was degraded to fragments which migrated in the front of the SDS-PAGE gels. Similarly, tryptic-chymotryptic digests of the iodinated SAP 614 were compared with such digests of canine SAP-35. Chymotryptic-tryptic digests of SAP-35 resulted in at least six highly reproducible spots as previously reported $(17,19,23)$. In contrast, while some labeled peptides of $\mathrm{Mr}=6,000$ and 14,000 were detected, most of the labeled material remained near the origin of the plates and no distinct peptides were identified which comigrated with the peptides identified from SAP-35 (not shown).

The marked differences between SAP 6-14 and SAP-35 in terms of solubility in organic solvents, and in their sensitivity to degradation by proteases and endoglycosidase $F$, also supported the concept that these proteins are not closely related. In addition, amino acid composition of SAP 6-14 was determined from canine and bovine preparations, and the results given in Table 1. The amino acid composition of canine SAP-35 previously reported by our laboratory (Table 1), is clearly distinct from the amino acid composition of SAP 6-14. The relative proportion of leucine and cysteine in hydrophobic SAP 6-14, for example, is much higher than in SAP-35. The amino acid composition results in Table 1 indicate that it is highly unlikely that SAP 6- 


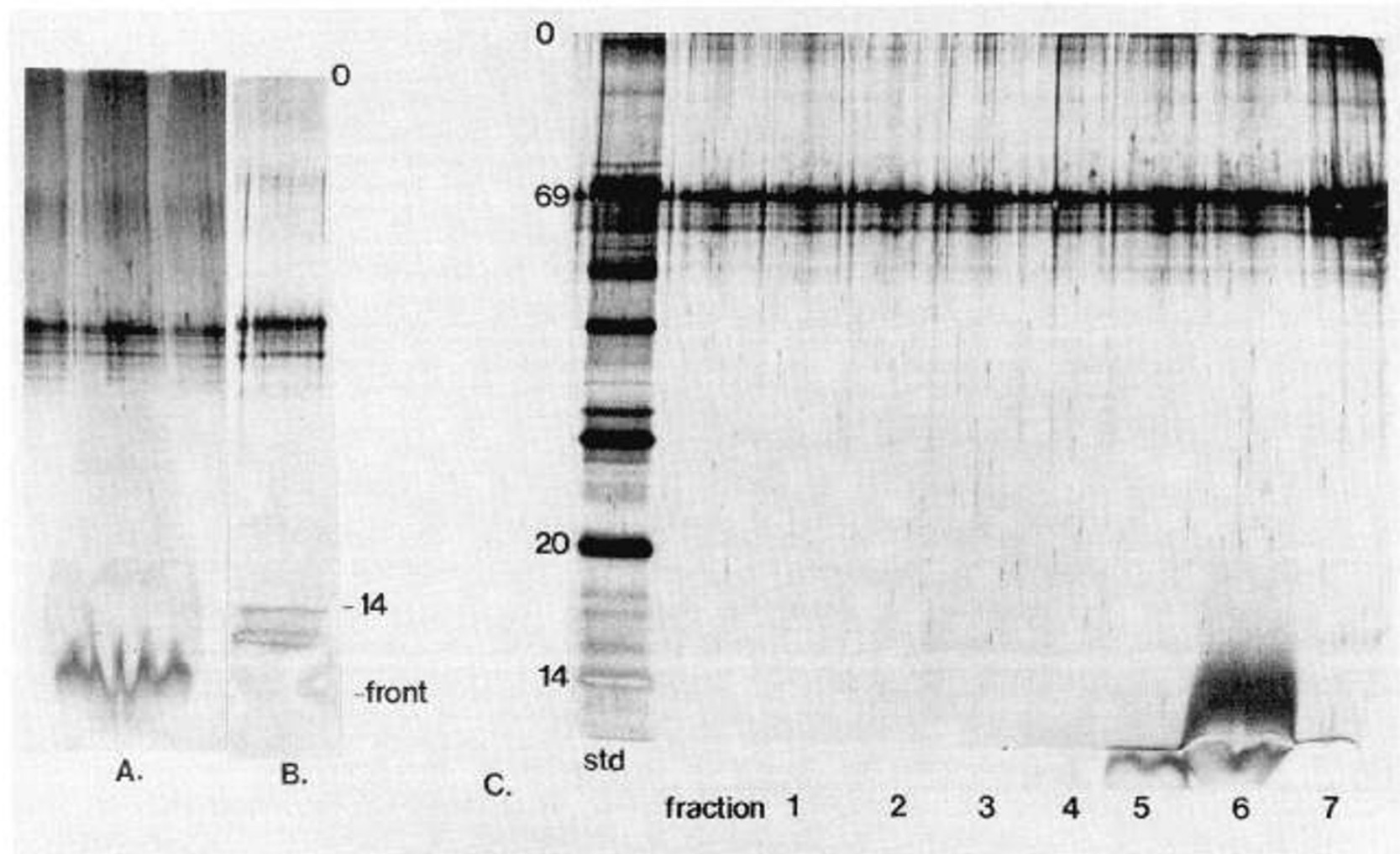

Fig. 2. Purification of canine SAP 6-14 from ether/ethanol extracts of surfactant assessed by silver staining. $A$ represents starting material. Lipid and protein migrated near the buffer front. Purified canine SAP 6-14 $(B)$ migrates as two distinct bands of 6,000 and 14,000 daltons. Faint amounts are observed at $\mathrm{Mr}=20,000$ and 26,000 although not visualized here. $C$ represents the profile of protein elution from the Biosil-HA column by increasing proportions of methanol in chloroform as described in "Materials and methods." Staining at $65-69,000$ daltons is the $\beta$-mercaptoethanol artifact. Fraction 6 contained protein assessed either by fluorescamine assay or by silver staining after elution by 3:2 chloroform:methanol. This eluted material was then utilized for Sep-pack chromatography for further delipidation as described in "Materials and methods." Delipidated protein, approximately $2 \mu \mathrm{g}$, is shown in $B$. The electrophoresis buffer front is marked $(f)$.

14 originated from linear amino acid sequences derived from SAP-35.

To further assess possible relationships among these proteins, monospecific antisera were prepared against bovine SAP-35 and were utilized for immunoblot analysis of whole bovine surfactant and purified bovine SAP 6-14. Anti-SAP-35 readily detected a broad band of protein $\mathrm{Mr}=35,000$ but did not react with protein $\mathrm{Mr}=6,000$ and 14,000 (Fig. 4).

Protein in surfactant extract replacement preparations. Relationships among SAP 6-14 and protein from the surfactant extract replacement preparations CLSE and surfactant-TA were assessed. Ethanol-ether extracts of these preparations did not result in detectable precipitation of SAP-35. CLSE and surfactant-TA were then purified as described for the surfactant-associated ether/ethanol soluble proteins described above. The results shown in Figure 5 demonstrate that the identical 6,000 and 14,000 dalton protein detected in ether/ethanol extracts of lung surfactant was present in both CLSE and surfactant TA; proteins of larger molecular weight were not detected in significant quantities. In particular, protein corresponding to SAP-35 was not detected by immunoblot analysis with anti-SAP-35 antibodies.

Comparative biophysical activity of whole surfactant and CLSE extract. In order to permit inferences about the importance and relative effectiveness of SAP 6-14 in terms of biophysical activity, it was necessary to compare the surface activity of the CLSE replacement extract with that of the whole calf LS from which it is derived. This was done by means of both adsorption and oscillating bubble measurements (see "Materials and methods") which documented that the biophysical activity of CLSE and whole LS was equivalent, even though the former contained only the SAP 6-14, without significant SAP-35.

The isolated adsorption facility of LS and CLSE is shown in the surface pressure-time $(\pi-t)$ isotherms of Figure 6 for a bulk phase concentration of $0.063 \mathrm{mg}$ of surfactant phospholipid per $\mathrm{ml}$. The CLSE is the same preparation studied for protein content in Figure 5. Isotherms are represented for a number of different conditions known to affect LS or CLSE adsorption facility. Curve 1 on Figure 6 shows that CLSE dispersed in saline by sonication for $1 \mathrm{~min}$ at $25 \mathrm{~W}$ power $(2,37)$ adsorbs with extreme rapidity to surface pressures greater than 45 dynes $/ \mathrm{cm}$. Natural LS with $\mathrm{Ca}^{++}$ions added in curve 3 , and CLSE dispersions formed by mechanical vortexing $(2,36,37)$ in curve 2 , adsorb slightly less rapidly at this low subphase concentration of $0.06 \mathrm{mg}$ phospholipid/ml. At higher concentrations of $0.125 \mathrm{mg} / \mathrm{ml}$, however, both CLSE dispersed by vortexing and natural LS with calcium ions exhibited the same maximal adsorption facility ${ }^{1}$ as sonicated CLSE dispersions (not shown explicitly). These data demonstrate that in terms of adsorption behavior, the CLSE replacement extract has activity as high as that of whole surfactant.

Because dynamic surface tension lowering properties are

\footnotetext{
${ }^{1}$ The term "maximal adsorption" is used to denote adsorption in seconds to surface pressures approaching the equilibrium spreading pressure limit of phospholipids, which does not exceed $45-50$ dynes/cm (3). It is important to note that mixtures of synthetic phospholipids alone, which are of similar composition to CLSE but without any protein, are not able to achieve maximal adsorption equivalent to LS and CLSE preparations in Figure 6, as shown previously by Notter et al. (2). This is presumptive evidence that the protein in LS and CLSE, even though present in small amounts particularly in the latter, is important for optimal surface activity.
} 


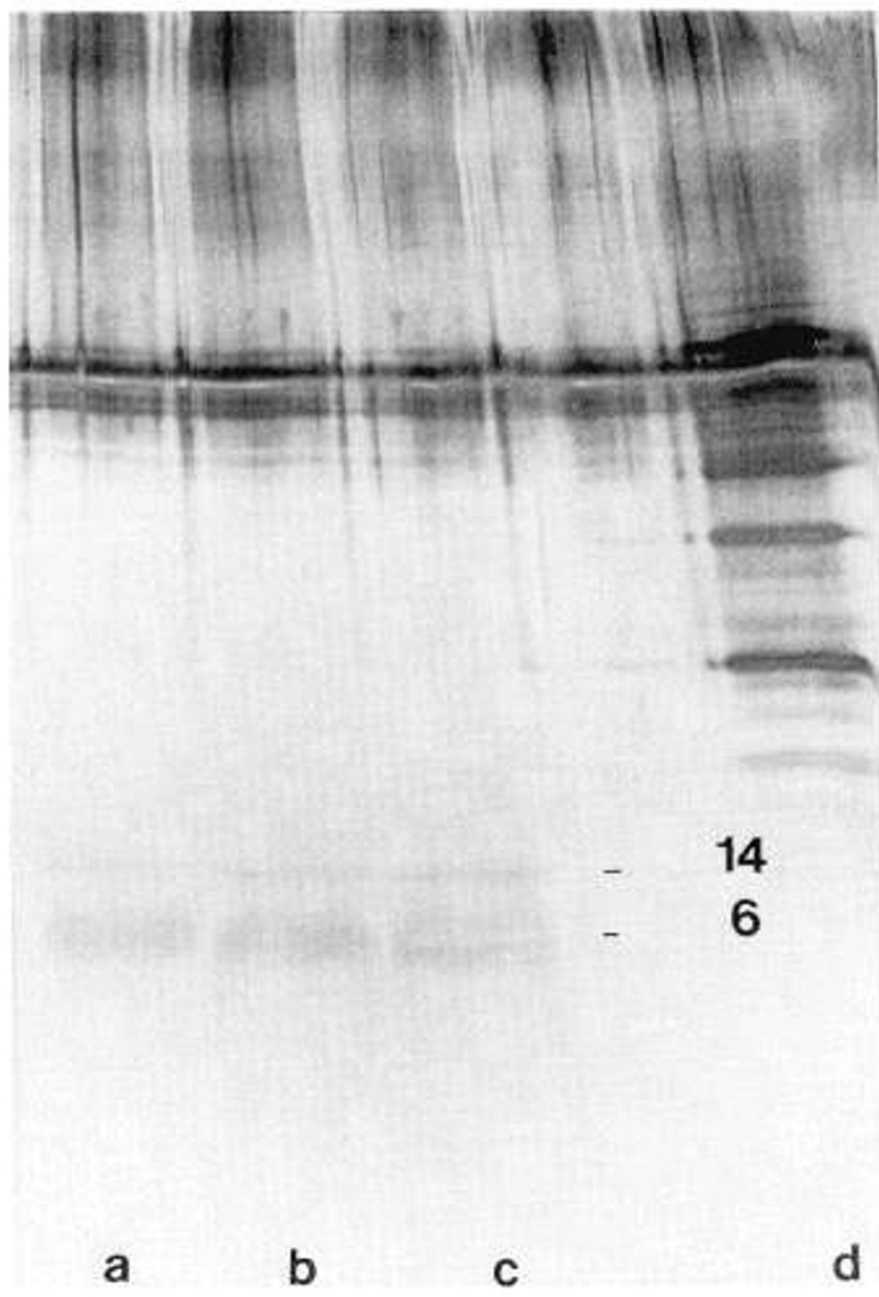

Fig. 3. SAP 6-14 from human, canine, and bovine surfactants. Proteins were purified and delipidated as described in "Materials and methods," and applied to $10-20 \%$ sodium dodecylsulfate-polyacrylamide gel electrophoresis gels in presence of $\beta$-mercaptoethanol. Each lane represents approximately $2 \mu \mathrm{g}$ proteins detected by silver staining. The purified protein from each species, $a=$ human, $b=$ bovine, $c=$ canine, migrated with $\mathrm{Mr}=6,000$ and 14,000 . The $\beta$-mercaptoethanol artifact is also observed at $\mathrm{Mr}=65-70,000$. Standard molecular weight markers are seen on the right.

thought to be critical for LS function in respiration $(3,46)$, the surface activity of LS and CLSE was also defined here by oscillating bubble measurements. Results of these determinations are shown in Table 2 . The data show that both LS and CLSE can generate minimum surface tensions less than 1 dyne $/ \mathrm{cm}$ for concentrations ranging from 0.5 to $5 \mathrm{mg} / \mathrm{ml}$. In addition, at a given concentration, the times necessary for this minimum to be reached after the start of bubble pulsation were essentially equivalent for LS compared to CLSE across this concentration range studied. These results demonstrate the comparable dynamic surface activity of whole surfactant and the CLSE preparations studied here for protein composition.

\section{DISCUSSION}

In the present work we have isolated hydrophobic proteins of molecular weight 6,000 and 14,000 daltons from pulmonary surfactant from human, canine, and bovine lung lavage. These proteins were readily distinguished from surfactant associated SAP-35 by peptide mapping, resistance to proteases, and endoglycosidase $\mathrm{F}$, as well as by amino acid composition. SAP 6-14
Table 1. Amino acid composition of SAP 6-14 and SAP-35*

\begin{tabular}{|c|c|c|c|}
\hline & $\begin{array}{c}\text { Dog } \\
\text { residues/molecul }\end{array}$ & $\begin{array}{c}\text { Cow } \\
\text { e† residues/molecule } \dagger\end{array}$ & $\begin{array}{c}\text { Canine SAP-35 } \\
\text { residues/molecule }\end{array}$ \\
\hline CM-Cys & 4 & 9 & 6 \\
\hline Asx & 4 & 5 & 27 \\
\hline Thr & 2 & 1 & 11 \\
\hline Ser & 8 & 1 & 17 \\
\hline Glx & 4 & 2 & 30 \\
\hline Pro & 7 & 9 & 13 \\
\hline Gly & 12 & 9 & 40 \\
\hline Ala & 5 & 5 & 15 \\
\hline Val & 5 & 9 & 14 \\
\hline Met & 4 & 2 & 5 \\
\hline Ile & 6 & 10 & 9 \\
\hline Leu & 17 & 20 & 19 \\
\hline Tyr & 2 & 2 & 9 \\
\hline Phe & 4 & 1 & 6 \\
\hline His & & 1 & 6 \\
\hline Lys & 3 & 4 & 10 \\
\hline Trp & 1 & ND§ & ND \\
\hline Arg & 4 & 5 & 11 \\
\hline Hyp & $(-) \|$ & $(-)$ & $(+) \pi$ \\
\hline
\end{tabular}

* Purified protein samples were hydrolyzed in $300 \mu 15.7 \mathrm{~N} \mathrm{HCl}, 0.3 \%$ phenol, $0.01 \% \beta$-mercaptoethanol at $110^{\circ} \mathrm{C}$ under vacuum. Free amino acids were resolved using a Beckman 6300 acid analyzer.

$\dagger$ Estimated average molecular weight $=10,000$ daltons.

$\$$ Estimated molecular weight $=26,000$ daltons for peptide portion.

$\S$ Not determined.

\| Absent.

I Present.

is a distinct protein and does not represent material previously termed "apoprotein B" since, in contrast to SAP 6-14, the smaller molecular weight protein designated apoprotein $B$ was isolated from ether:ethanol precipitates of canine surfactant (16). Hydrophobic small molecular weight proteins were found to be the only significant proteins detected by silver stain analysis of the exogenous surfactant replacement extracts CLSE (formerly called calf lung lipid) and surfactant-TA. The CLSE preparation studied here displayed all the beneficial biophysical properties of natural surfactant in terms of dynamic surface tension lowering and adsorption, in agreement with earlier biophysical studies $(2,3$, 47). In addition, the physiologic activity of CLSE has been verified in previous studies involving restoration of lung function and mechanics in several surfactant-deficient animal models ( 36 , $37,48,49)$ and in three recently reported trials of surfactant replacement therapy for human infants with respiratory distress syndrome (11-13). Surfactant properties and physiologic efficacy of surfactant-TA have also been demonstrated in both animal and clinical studies $(10,14,50)$.

SAP 6-14 isolated here from mammalian surfactants and from replacement surfactant preparations was found to be remarkably hydrophobic in nature. The amino acid compositions determined for the cow and dog proteins, although not identical, were quite similar. The SAP 6-14 proteins from these species were also similar in terms of electrophoretic migration in SDS-PAGE gels. SAP 6-14 from all animals tested was highly resistant to protease digestion. These results suggest that SAP 6-14 are related peptides with similar structure and functions in the species tested (dog, human, bovine). We suggest that higher molecular weight forms $(\mathrm{Mr}=14,000,20,000$, and 26,000) represent multimers of the SAP 6 protein. Recent immunologic studies and Nterminal amino acid determination of the SAP 6-14 preparations support this premise (51; Whitsett JA, Hull WM, Ohning B, Ross G, Weaver T, Meuth J, unpublished observations).

Previous studies regarding the timing of the appearance of small molecular weight proteins in lung lavage after radiolabeling 


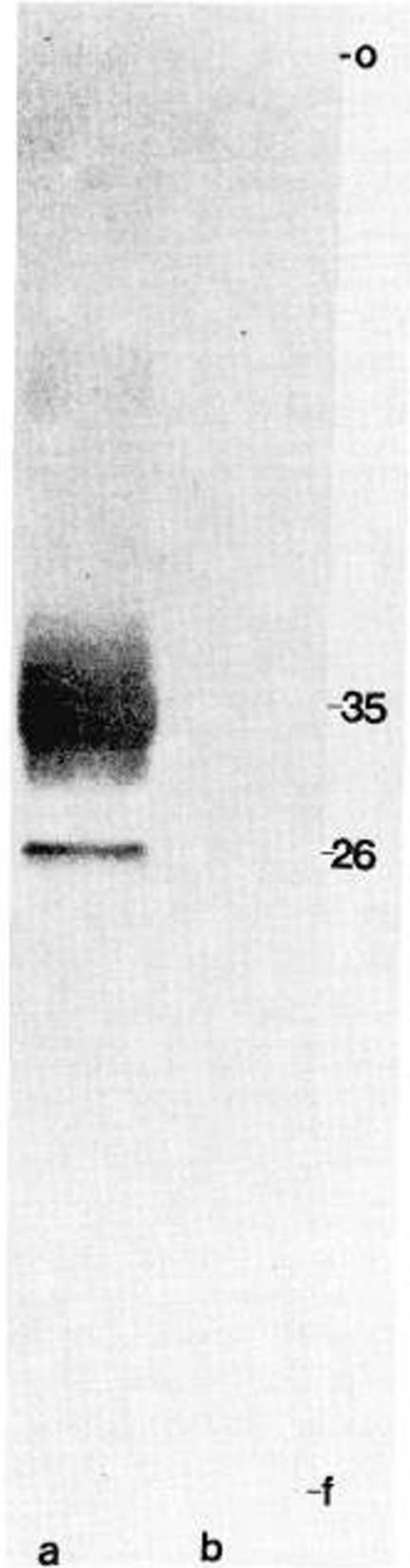

Fig. 4. Immunoblot analysis of bovine surfactant (LS) and purified SAP 6-14 using monospecific antisera against bovine SAP-35. $A$ represents approximately $50 \mu \mathrm{g}$ protein of bovine surfactant (LS). Immunoreactivity is noted at $\mathrm{Mr}=26,000$ and $\mathrm{Mr}=32-36,000$ (SAP-35) and slight reactivity at 70,000 (dimer of SAP-35). No reactivity was noted against $\mathrm{Mr}=6,000$ and 14,000 protein in LS or in $B$ against purified SAP 6-14 $(2 \mu \mathrm{g})$.

have suggested that they might be generated by proteolysis of the major surfactant associated protein of $\mathrm{Mr}=35,000$ daltons (32). However, while smaller molecular weight fragments of SAP-35 have been obtained and purified from ether:ethanol precipitates of canine surfactant (17; Ross G, Meuth J, Whitsett JA, unpublished results), they are distinct from SAP 6-14 in terms of amino acid composition, size, and their lack of partition into organic solvents. However, fragments of SAP-35 likely represent, in part, the protein previously designated "apoprotein B." In the present study, monospecific antisera generated against purified SAP-35, which readily detected SAP-35 in bovine surfactant, failed to react with SAP 6-14 by immunoblot analysis. Further, the relative abundance of cysteine and leucine, and the lack of hydrox-

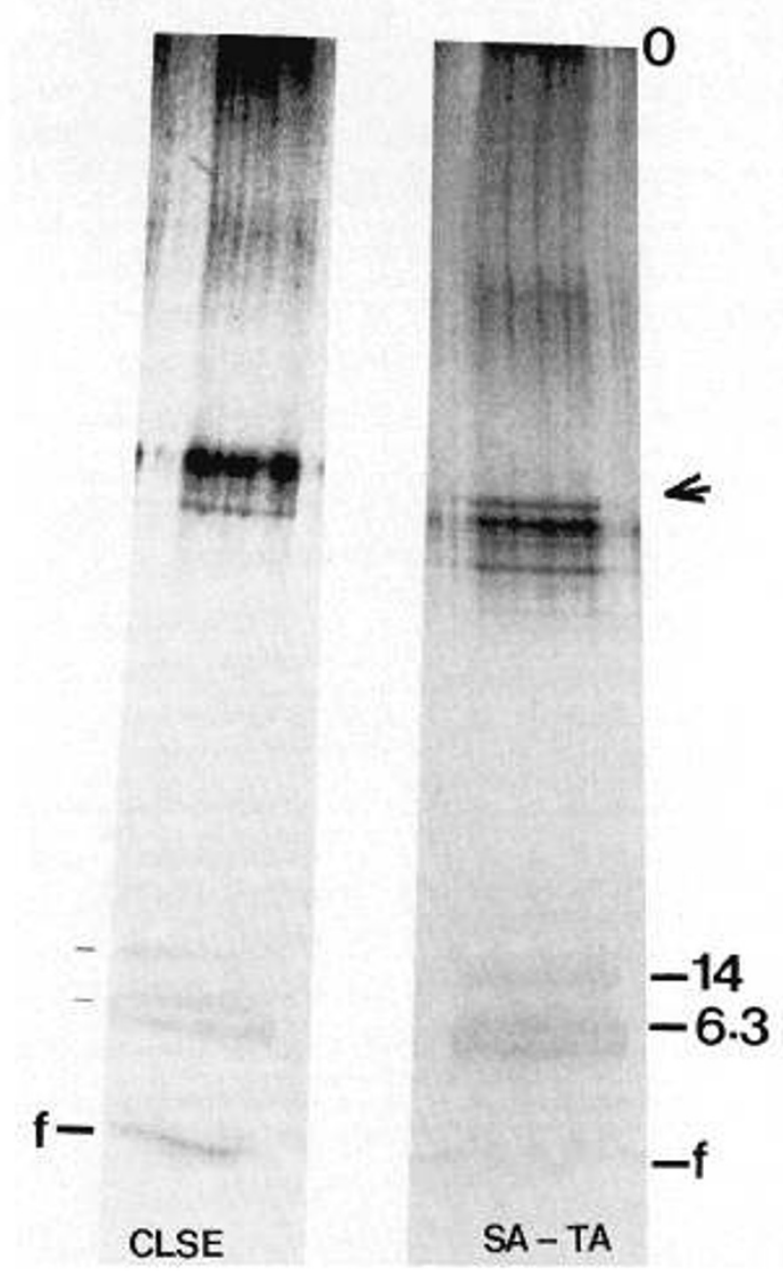

Fig. 5. Silver stain analysis of protein in CLSE and surfactant TA. Approximately $2 \mu \mathrm{g}$ purified protein from CLSE was separated in presence of $\beta$-mercaptoethanol with 3-27\% sodium dodecylsulfate-polyacrylamide gel electrophoresis and silver stained. SAP 6-14 is marked, $\mathrm{Mr} \times$ $10^{-3}$. The front is marked $(F)$. The arrow marks the $\beta$-mercaptoethanol artifact at $\mathrm{Mr}=65,000$ daltons. Similar gel for $2 \mu \mathrm{g}$ protein purified from surfactant-TA $(S-T A)$ is seen at the right.

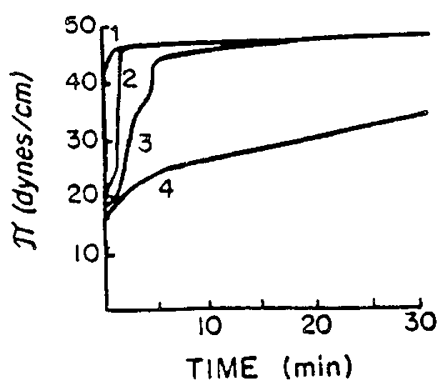

Fig. 6. Adsorption isotherms of natural LS and the surfactant extract CLSE under varying conditions. Surfactant mixtures were dispersed (CLSE) or resuspended (LS) in $0.15 \mathrm{M} \mathrm{NaCl}$ as described in "Materials and methods." Final subphase concentrations used was $0.063 \mathrm{mg}$ phospholipid $/ \mathrm{ml}$. Surface pressure is the amount of surface tension lowering generated by the surfactant film below that of the surfactant-free subphase (which was 70.5 dynes $/ \mathrm{cm}$ at $35^{\circ} \mathrm{C}$ ) for these adsorption experiments. Specific isotherms are: 1. CLSE dispersed by sonication; 2. CLSE dispersed by vortexing; 3 . LS with $1.4 \mathrm{mM} \mathrm{Ca}^{++}$ions; and 4 . LS without added $\mathrm{Ca}^{++}$. 
Table 2. Dynamic surface tension lowering activity of whole LS and CLSE replacement extract on oscillating bubble

\begin{tabular}{cccc}
\hline Surfactant mixture* & $\begin{array}{c}\text { Concentration } \dagger(\mathrm{mg} \\
\text { phospholipid/ml) }\end{array}$ & $\begin{array}{c}\text { Minimum surface tension } \\
\text { (dynes/cm) }\end{array}$ & $\begin{array}{c}\text { Time to minimum tension } \neq \\
\text { (mins) }\end{array}$ \\
\hline 1. LS & 5 & $<1$ & $<1$ \\
2. CLSE & 5 & $<1$ & $<1$ \\
3. LS & 2 & $<1$ & 4 \\
4. CLSE & 2 & $<1$ & 5 \\
5. LS & 0.75 & $<1$ & 6 \\
6. CLSE & 0.75 & $<1$ & 7 \\
7. LS & 0.5 & $<1$ & 10 \\
8. CLSE & 0.5 & $<1$ & 12 \\
\hline
\end{tabular}

* Surfactant is either whole LS or CLSE obtained from the same calf lung lavage as described in "Materials and methods" and detailed previously, eg. References 2 and 3.

† Concentration is expressed in mg of surfactant phospholipid per $\mathrm{ml}$ of $0.15 \mathrm{M} \mathrm{NaCl}$ subphase in which an air bubble is formed at time zero, and pulsation started at 20 cycles/min. LS was resuspended from a centrifuged pellet for bubble studies, while CLSE was dispersed by mechanical vortexing after evaporation from chloroform under nitrogen $(3,36,37)$. The presence of calcium ions in the subphase did not appreciably affect the bubble results shown for CLSE or LS, although the isolated adsorption of the latter is enhanced by calcium (see text for details).

$\$$ Values shown are from at least two closely reproducible determinations.

yproline in SAP 6-14 also support its distinction from the SAP35 or its fragments. In addition, the resistance of SAP 6-14 to protease digestion was demonstrated after treatment with trypsin, chymotrypsin, pepsin, thermolysin, and papain. Similarly, endoglycosidase $F$ (in the presence or absence of detergent) did not significantly alter the size or size heterogeneity of SAP 6-14. By contrast, under identical conditions, proteases and endoglycosidase F actively degraded SAP-35. Digestion of SAP-35 with these various proteases, however, did not result in the generation of protease resistant fragments of 6,000 and 14,000 daltons.

The amino acid composition of SAP 6-14 is similar to that demonstrated in peptides from porcine lungs previously reported by Phizackerley et al. (30) and is distinct from "apoprotein B" (16). In the studies of Phizackerley et al. (30) several peptides of approximately $9-16,000$ daltons were identified utilizing purification and delipidation procedures similar to those used here. Phizackerley et al. (30) identified an identical $\mathrm{NH}_{2}$-terminal amino acid from several of these proteins. These findings and the remarkable resistance of all SAP 6-14 peptides studied to protease and endoglycosidase digestion, as well as their equivalent partition into the organic rather than aqueous solvents, strongly support a similar functional role and structural relatedness (possibly as oligomers) for these low molecular weight hydrophobic proteins observed in the different species studied.

Aside from comparing and contrasting the composition and properties of SAP-35 and SAP 6-14, a major emphasis of our experiments was to characterize the protein component of lung surfactant extract mixtures. In particular, because of the importance of the clinical use of surfactant replacement extracts, and the lack of clarity regarding the nature and origins of the proteins in those preparations, we compared the hydrophobic proteins purified from lung lavage with the proteins isolated from the clinically tested surfactant extract replacement preparations CLSE and surfactant-TA (10-14). These preparations contained the hydrophobic SAP 6-14 protein, which comigrated with those isolated from mammalian whole surfactant. Surfactant associated SAP-35, and the more abundant serum proteins present in whole surfactant, were not present in significant quantities in CLSE or surfactant-TA. Results for surfactant-TA, confirm and extend the previous work of Tanaka et al. (31) and Suzuki et al. (29) who demonstrated small molecular weight proteins in surfactant extracts of minced lungs from cows and porcine surfactant, the former being the base material for surfactant-TA (14). The amino acid composition reported by Tanaka et al. (31) for surfactant extracts from minced cow lungs was similar to that obtained for the bovine SAP 6-14 presently reported.

In terms of surfactant function, our results show that SAP 614 protein, in the presence of natural surfactant lipids, is associated with full biophysical activity of the CLSE surfactant extract used for replacement therapy for respiratory distress syndrome (11-13). This biophysical activity of rapid adsorption and good dynamic surface tension lowering has been demonstrated to result in beneficial effects of CLSE on lung function and mechanics in surfactant-deficient animal lung models $(3,36,37$, 48,49 ) and in clinical therapy with respiratory distress syndrome infants (9-13). Similar findings hold for the related lung surfactant extract preparation, surfactant-TA (14). The precise role of SAP 6-14 in this activity remains to be clarified. SAP 6-14 is markedly resistant to protease digestion supporting its stability and suitability for replacement surfactants. While natural surfactant from lung lavage contains a large number of detectable proteins, including both serum and nonserum protein, the major protein, SAP-35, and the other less abundant proteins do not appear to be required for the biophysical activity of the CLSE and surfactant-TA surfactant preparations.

It should be noted that our results do not exclude the possibility that SAP-35 plays a role in lung surfactant physical physical function in vivo. Surfactant extracts such as CLSE are not equivalent to natural LS; they are dispersed by mechanical means, e.g. sonication, mechanical agitation, in an aqueous phase prior to use. This allows extracts such as CLSE or surfactant-TA to achieve active aqueous dispersion microstructures not available to natural LS in vivo. Notter et al. (52) have recently shown that CLSE can adsorb as rapidly as natural LS without forming the distinctive microstructure of tubular myelin, associated with optimal adsorption of the latter (52-54). Thus, SAP35 could be involved in natural LS activity in vivo, but in ways that are by-passed in mechanically dispersed extracts so that the extracts can be surface active without the necessity for SAP-35. In a practical sense, however, the results here show that good biophysical activity in exogenous surfactants can be achieved with extracts containing only SAP 6-14. Moreover, it is this protein which is so specifically associated with surfactant phospholipids that it retains this relationship to the extent of remaining with them during organic solvent extraction. The further understanding of SAP 6-14 and clarification of its potential biophysical properties may lead to new strategies for the treatment of hyaline membrane disease and other surfactant deficient states. For example, if semisynthetic surfactants are formulated in vitro using synthetic phospholipids combined with small amounts of surfactant proteins, this might specifically involve SAP 6-14.

\section{REFERENCES}

1. King RJ, Carmichael MC, Horowitz PM 1983 Reassembly of lipid-protein complexes of pulmonary surfactant. Proposed mechanism of interaction. J Biol Chem 258:10672-10680 
2. Notter RH, Finkelstein JN, Taubold RD 1983 Comparative adsorption of natural lung surfactant, extracted phospholipids, and artificial phospholipid mixtures to the air-water interface. Chem Phys Lipids 33:67-80

3. Notter RH 1984 Surface chemistry of pulmonary surfactant: interactions of individual components. In: Robertson B, van Golde LMG, Batenburg JJ (eds) Pulmonary Surfactant. Elsevier, The Netherlands, pp 17-65

4. Tanaka Y, Takei T, Masuda K 1983 Lung surfactants. III. Correlations among activities in vitro, in situ and in vivo and chemical composition. Chem Pharm Bull 31:4110-4115

5. Suzuki Y 1982 Effect of protein, cholesterol, and phosphatidylglycerol on the surface activity of the lipid-protein complex reconstituted from pig pulmonary surfactant. Lipid Res 23:62-69

6. King RJ, MacBeth MC 1981 Interaction of the lipid and protein components of pulmonary surfactant. Role of phosphatidylglycerol and calcium. Biochim Biophys Acta 647:159-168

7. Meban C 1981 Effect of lipids and other substances on the adsorption of dipalmitoyl phosphatidylcholine. Pediatr Res 15:1029-103

8. King RJ, MacBeth MC 1979 Physicochemical properties of dipalmitoyl phosphatidylcholine after interaction with an apolipoprotein of pulmonary surfactant. Biochim Biophys Acta 557:86-101

9. Smyth JA, Metcalf IL, Duffy P, Possmayer F, Bryan MH, Enhorning G 1983 Hyaline membrane disease treated with bovine surfactant. Pediatrics 71:913917

10. Fujiwara T, Chida S, Watabe Y, Maeta H, Morita T, Abe T 1980 Artificial surfactant therapy in hyaline membrane disease. Lancet 1:55-59

11. Kwong MS, Egan EA, Notter RH, Shapiro DL 1985 A double blind clinical trial of calf lung lipid for the prevention of hyaline membrane disease in extremely premature infants. Pediatrics 76:585-592

12. Shapiro DL, Notter RH, Morin FC, Deluga K, Golub LM, Sinkin R, Weiss K, Cox C 1985 A double-blind, randomized trial of a calf lung surfactant extract administered at birth to very premature infants for prevention of the respiratory distress syndrome. Pediatrics 76:593-599

13. Enhorning G, Shennen A, Possmayer F, Dunn M, Chen CP, Milligan J 1985 Prevention of neonatal respiratory distress syndrome by tracheal instillation of surfactant: a randomized clinical trial. Pediatrics 76:145-153

14. Fujiwara T 1984 Surfactant replacement in neonatal RDS. In: Robertson B, van Golde LMG, Batenburg JJ (eds) Pulmonary Surfactant. Elsevier, Amsterdam, The Netherlands, pp 479-503

15. King RJ, Clements JA 1972 Surface active materials from dog lung. II. Composition and physiological correlations. Am J Physiol 223:715-726

16. King RJ, Klass DJ, Gikas EG, Clements JA 1973 Isolation of apoproteins from canine surfactant material. Am J Physiol 244:788-795

17. Ross G, Meuth J, Ohning B, Yangkil K, Whitsett JA 1985 Purification of canine surfactant-associated glycoprotein(s) A: identification of a collagenase resistant domain. Biochim Biophys Acta (in press)

18. White RT, Damm D, Miller J, Spratt K, Schilling J, Hawgood S, Benson B, Cordell B 1985 Isolation and characterization of the human pulmonary surfactant apoprotein gene. Nature 317:361-363

19. Weaver TE, Hull WM, Ross GF, Whitsett JA 1985 Intracellular and oligomeric forms of surfactant-associated apolipoprotein(s) A in the rat. Biochim Biophys Acta 827:260-267

20. Weaver TE, Whitsett JA, Hull WM, Ross GF 1985 Identification of canine pulmonary surfactant-associated glycoprotein(s) A precursors. J Appl Physiol 58:2091-2095

21. Whitsett JA, Weaver TE, Hull WM, Ross G, Dion C 1985 Synthesis of surfactant-associated glycoprotein(s) A by rat Type II epithelial cells. Primary translation products and post-translational modification. Biochim Biophys Acta 828:162-171

22. Floros J, Phelps DS, Taeusch HW 1985 Biosynthesis and in vitro translation of the major surfactant-associated protein from human lung. $J$ Biol Chem 260:495-500

23. Whitsett JA, Hull WM, Ross G, Weaver TE 1985 Characteristics of human surfactant-associated glycoprotein(s) A. Pediatr Res 19:501-508

24. King RJ, Klass DJ, Gikas EG, Clements JA 1973 Isolation of apoproteins from canine surface active material. Am J Physiol 224:788-795

25. Wright JR, Benson BJ, Williams MC, Goerke J, Clements JA 1984 Protein composition of rabbit alveolar surfactant subfractions. Biochim Biophys Acta 791:320-332

26. Claypool WD, Wang DL, Chander A, Fisher AB 1984 An ethanol/ether soluble surfactant augments liposome uptake by isolated granular pneumocytes. J Clin Invest 74:677-684
27. Katyal SL, Singh G 1984 Analysis of pulmonary surfactant apoproteins by isoelectric focusing. Biochim Biophys Acta 794:411-418

28. Williams MC, Benson BJ 1981 Immunocytochemical localization and identification of the major surfactant protein in adult rat lung. $J$ Histochem Cytochem 29:291-305

29. Suzuki Y, Nakai E, Ohkawa K 1982 Experimental studies on the pulmonary surfactant reconstitution of surface-active material. J Lipid Res 23:53-61

30. Phizackerley PJR, Town M-H, Newman GE 1979 Hydrophobic proteins of lamellated osmiophilic bodies isolated from pig lung. Biochem $\mathbf{J}$ 183:731736

31. Tanaka Y, Takei T, Kanazana Y 1983 Lung surfactants. II. Effects of fatty acids triacylglycerols and protein on the activity of lung surfactant. Pharm Bull 31:4100-4109

32. King RJ, Martin H, Mitts D, Holmstron FM 1977 Metabolism of the apoproteins in pulmonary surfactant. J Appl Physiol 42:483-491

33. Phelps DS, Taeusch HW, Benson B, Hawgood S 1984 An electrophoretic and immunochemical characterization of human surfactant-associated proteins. Biochim Biophys Acta 791:226-238

34. Böhlen P, Stein S, Dairman W, Udenfriend S 1973 Fluorometric assay of proteins in the nanogram range. Arch Biochem Biophys 155:213-220

35. Bligh E, Dyer W 1959 A rapid method of total lipid extraction and purification. Can J Biochem 37:911-917

36. Egan EA, Notter RH, Kwong MS, Shapiro DL 1983 Natural and artificial lung surfactant replacement therapy in premature lambs. J Appl Physiol 55:875883

37. Notter RH, Egan EA, Kwong MS, Holm BA, Shapiro DL 1985 Lung surfactant replacement with lipids extracted from bovine lung lavage: effects of dispersion technique, dose and gestational age. Pediatr Res 19:569-577

38. Touchstone J, Chen J, Beaver K 1980 Improved separation of phospholipids in thin layer chromatography. Lipids 15:61-62

39. Ames B 1966 Assay of inorganic phosphate, total phosphate and phosphates. Methods Enzymol 8:115-118

40. Lowry OH, Rosenbrough NJ, Farr AL, Randall RJ 1951 Protein measurement with the folin-phenol reagent. J Biol Chem 193:265-275

41. Laemmli $U 1970$ Cleavage of structural proteins during the assembly of the head bacteriophage $T_{4}$. Nature 227:680-685

42. Sammons D, Adams LD, Nishizawa EE 1981 Ultrasensitive silver-based color staining of polypeptides in polyacrylamide gels. Electrophoresis 2:135-141

43. Towbin H, Staehelin T, Gordon J 1979 Electrophoretic transfer of proteins from polyacrylamide gels to nitrocellulose sheets: procedure and some applications. Proc Natl Acad Sci USA 76:4350-4354

44. Gibson W 1974 Polyoma virus proteins: a description of the structural proteins of the viron based on polyacrylamide gel electrophoresis and peptide analysis. Virology 62:319-336

45. Enhorning G 1977 Pulsating bubble technique for the evaluation of pulmonary surfactant. J Appl Physiol 43:198-203

46. Notter RH, Finkelstein JN 1984 Pulmonary surfactant: An interdisciplinary approach. J Appl Physiol 57:1613-1624

47. Metcalfe IL, Enhorning G, Possmayer F 1980 Pulmonary surfactant-associated proteins: their role in the expression of surface activity. J Appl Physiol 40:3441

48. Metcalfe IL, Pototschnik R, Burgoyne R, Enhorning G 1982 Lung expansion and survival in rabbit neonates treated with surfactant extract. J Appl Physio 53:838-843

49. Bermel MA, McBride JT, Notter RH 1984 Lavaged excised rat lungs as a model of surfactant deficiency. Lung 162:99-113

50. Vidyasagar D, Maeta $H$, Raju TNK, John E, Bhat $R$, Go M, Dahiya $U$ Roberson Y, Yamin A, Narula A, Evans M 1985 Bovine surfactant (surfactant-TA) therapy in immature baboons with hyaline membrane disease Pediatrics 75:1132-1142.

51. Whitsett JA, Hull WM, Ohning B, Ross GF, Weaver TE 1986 Immunologic identification of pulmonary surfactant associated protein of $\mathrm{Mv}=6,000$. Pediatr Res (in press)

52. Notter RH, Penney DP, Finkelstein JN, Shapiro DL 1985 Adsorption of natural lung surfactant and phospholipid extracts related to tubular myelin formation. Pediatr Res (in press)

53. Benson BJ, Hawgood S, Williams MC 1984 Role of apoprotein and calcium ions in surfactant function. Exp Lung Res 6:223-236

54. Benson BJ, Williams MC, Sueishi K, Goerke J, Sargeant T 1984 Role of calcium ions in the structure and function of pulmonary surfactant. Biochim Biophys Acta 793:18-27 